Research article

\title{
THE ROLE OF APOPTOSIS AND AUTOPHAGY IN BOVINE ABORTIONS ASSOCIATED WITH BRUCELLA SPP.
}

\author{
OZKARACA Mustafa ${ }^{1 *}$, CERIBASI Songul ${ }^{2}$, CERIBASI Ali Osman ${ }^{2}$, KILIC Ayse ${ }^{3}$, \\ ONGOR Hasan ${ }^{4}$
}

${ }^{1}$ Department of Pathology, Faculty of Veterinary Medicine, Ataturk University, 25240 Yakutiye/ Erzurum, Turkey; ${ }^{2}$ Department of Pathology, Faculty of Veterinary Medicine, Firat University, 23119 Elazig, Turkey; ${ }^{3}$ Sivrice Vocational High School, Firat University, 23119 Elazig, Turkey; ${ }^{4}$ Department of Microbiology, Faculty of Veterinary Medicine, Firat University, 23119 Elazig, Turkey

(Received 11 June; Accepted 13 November 2015)

\begin{abstract}
This study is aimed to evaluate the relationship between the severity of apoptotic and autophagic cell death based on the distribution of Brucella spp. antigens in the lung, liver, kidney, spleen, brain, heart, skeletal muscle, mesenteric lymph node, and thymus tissue from bovine fetuses aborted due to natural infection with Brucella spp. The distribution of Brucella spp. antigens was immunohistochemically examined in the tissues of 16 aborted fetuses from cattle diagnosed with Brucella spp. infection by a polymerase chain reaction (PCR). In addition, immunostaining of primary antibodies for cleaved caspase 3 was performed to detect apoptosis, and immunostaining of Microtubule Associated Protein 1 Light Chain 3 Beta (LC3B) was used to detect autophagy in the Brucella spp.related abortions. Analysis of cellular death revealed strong immunopositivity in the lung, spleen, kidney, and thymus, moderate immunopositivity in the liver, mesenterial lymph nodes, and heart muscle and slight immunopositivity in the brain and skeletal muscle by staining of Brucellaspp. antigens. According to the immunohistochemical results, the immunopositivity of cleaved caspase 3 and LC3B was extremely high in the lung, thymus, spleen, kidney, and liver tissues. The immunostaining of cleaved caspase 3 in the lung, thymus, and kidney tissues was severe compared to that of LC3B. In the liver, spleen, and mesenterial lymph nodes, the immunopositivity of LC3B was higher than that of cleaved caspase 3. Bacterial antigens were highly evident in the lung, spleen, kidney, and thymus tissues of Brucella spp.-related bovine abortions, and both apoptosis and autophagy played a role in cellular death.
\end{abstract}

Key words: Brucella spp., cleaved caspase 3, immunohistochemistry, LC3B

\section{INTRODUCTION}

Brucellosis is caused by bacteria of the genus Brucella, which belongs to the family a2Proteobacteriacea [1].These gram-negative, aerobic facultative intracellular pathogens are coccobacillus shaped. They are not motile and do not form spores. Measuring

\footnotetext{
*Corresponding author: e-mail: mustafa.ozkaraca@atauni.edu.tr
} 
$0.5 \times 0.7 \times 1.5 \mu \mathrm{m}$, they exhibit low metabolic activity [2]. B. abortus, the etiologic agent of cattle and camel brucellosis, is the foremost cause of bacterial-induced abortion, although B. melitensisand B. suis may also be responsible [3,4]

Immunohistochemistry is one of the several methods used to diagnose Brucellaspp., and it has been used to detect Brucella spp.antigens in formalin-fixed, paraffin-embedded tissues in cows [5].

Different mechanisms of programmed cell death, including apoptosis, autophagy, and pyroptosis, have been described [6-9]. A growing number of intracellular bacterial pathogens have been identified as mediators of host cell apoptosis. Microorganisms use apoptosis to eliminate key immune cells or evade the host's defenses, affecting the course of different infections [10,11]. Caspases, a family of proteases of early evolutionary origin, mediate apoptosis [12]. Of these, caspase-3, which is an executive caspase, plays an active role in apoptosis [13]. Reports have indicated that intracellular agents, such as Legionella and Chlamydia, activate caspase-3 [10].

Autophagy is another cell death mechanism that can eliminate intracellular pathogens, including viruses, bacteria, or protozoa. It is one of the primary mechanisms of natural defense [14]. Autophagy has also been linked to the host cell control of different intracellular organisms, including L.pneumophila [15] and Coxiella burnetii [16]. The observation of the lipidated LC3 form within the autophagosome membrane is a widely used marker of ongoing autophagy [17,18].

The aim of the present study, a first on this particular topic, was to determine which cellular death mechanism was activated in spontaneous cattle abortions caused by natural infection with the intracellular bacterium Brucella spp. The distribution of Brucella spp. antigens and the mechanism of cell death (i.e., apoptosis or autophagy) were studied.

\section{MATERIAL AND METHODS}

\section{Sampling}

The study population consisted of 16 samples of spontaneously aborted fetuses from cattle diagnosed with Brucella spp. infection received in 2013 at the Elazig Veterinary Control Institute.

\section{Identification of Brucella spp.}

Abomasal contents and fetal lungs were cultured on 7\% blood agar (Oxoid, CM 271) and Brucella medium (Oxoid, CM 169), supplemented with a Brucella-selective supplement (Oxoid, SR 209E). The cultures were incubated at $37^{\circ} \mathrm{C}$ for $5-7$ days in aerobic and microaerobic conditions (Microaerobic kit, Merck, Anaerocult C). At the end of the incubation period, colonies were identified by the following tests: gram staining; morphology; culture characteristics; motility, catalase, urease, oxidase, and $\mathrm{H}_{2} \mathrm{~S}$ production; growth in the presence of $\mathrm{CO}_{2}$ and dyes; and agglutination using monospecific $\mathrm{A}$ and $\mathrm{M}$ antisera. 
Samples from the lung, liver, spleen, kidney, brain, heart, skeletal muscle, mesenteric lymph nodes, and thymus of seven aborted cattle fetuses free of Brucella spp. infection were used as negative controls.

\section{Conventional PCR assay}

Isolated strains from suspicious Brucella cultures were transferred into an Eppendorf tube containing $300 \mu \mathrm{l}$ of distilled water. DNA sample purification from these suspicious Brucella cultures was performed using a QIAamp DNA kit (Qiagen Courtaboeuf, France), following the manufacturer's recommendations.

This study used the PCR primers designed by Leal-Klevezas et al. [19]. These PCR primers are based on the DNA sequence of the gene that encodes the outer membrane protein (omp-2) reported for Brucella in the Genbank database [19]. The sequence of primer pairs was as follows: the forward primer sequence was 5'-GCGCTCAGGCTG CCGACGCAA-3', and the reverse primer sequence as 5'ACCAGCCAT'TGCGGTCGGTA-3'. The PCR reaction was performed in a $50 \mu \mathrm{l}$ reaction mixture containing $25 \mu \mathrm{l}$ of PCR Master Mix (Thermoscientific, Catalog No: K0171), $2.5 \mu$ of each primer, $15 \mu$ of sterile nuclease-free water, and $5 \mu$ l of template DNA. All the PCR reactions were performed at $94^{\circ} \mathrm{C}$ for $5 \mathrm{~min}$, followed by 30 cycles of $94^{\circ} \mathrm{C}$ for $1 \mathrm{~min}, 65^{\circ} \mathrm{C}$ for $1 \mathrm{~min}, 72^{\circ} \mathrm{C}$ for $1 \mathrm{~min}$, and a final extension at $72^{\circ} \mathrm{C}$ for $5 \mathrm{~min}$. The PCR-amplified products were examined by electrophoresis in a $1.5 \%$ agarose gel.

\section{Immunohistochemical examinations}

Samples of lung, liver, kidney, spleen, brain, heart, skeletal muscle, mesenteric lymph node, and thymus tissue from bovine fetuses aborted due to natural infection with Brucella spp. were fixed in 10\% neutral-buffered formalin. Following routine alcohol-xylol series, the tissues were embedded in paraffin blocks. Five micron-thick sections of the blocks were stained using the streptavidin-biotin system for the immunohistochemical identification of Brucella spp. antigen, apoptosis (cleaved caspase-3), and autophagy (LC3B) (Table 1). According to the proportion of all stained cells in 10 randomly chosen microscope fields, immunopositivity was defined as light (1) if less than $5 \%$, moderate (2) if between 5 and 15\%, and strong (3) if greater than $15 \%$.

Table 1. Antibody specificity, dilution rates and incubation times

\begin{tabular}{lccc}
\hline Antibody & $\begin{array}{c}\text { Dilution } \\
\text { Rates }\end{array}$ & $\begin{array}{c}\text { Incubation } \\
\text { Times }\end{array}$ & Commercially \\
\hline $\begin{array}{l}\text { Polyclonal Rabbit Brucella spp. } \\
\text { Polyclonal Rabbit Active/ }\end{array}$ & $1 / 500$ & 30 minutes (RT) & Pendik Veterinary Cont. Inst \\
$\begin{array}{l}\text { Cleaved Caspase 3 Antibody } \\
\text { Polyclonal Rabbit LC3/ }\end{array}$ & $1 / 300$ & 20 minutes (RT) Novus Biological (Cat No. NB600-1235) \\
$\begin{array}{l}\text { B Antibody } \\
\begin{array}{l}\text { Mouse and Rabbit Specific HRP/ } \\
\text { DAB Detection IHC kit }\end{array}\end{array}$ & $1 / 300$ & 20 minutes (RT) & Abcam (Cat. No. ab15323) \\
\hline
\end{tabular}




\section{RESULTS}

Brucella spp. were isolated from the abomasal contents and lungs of the 16 aborted cattle fetuses and confirmed by PCR. Sixteen DNA samples purified from these cultures were tested using omp 2 primers, and all tested samples gave a 113-bp PCR product with omp-2 primers (Fig. 1). No PCR product was observed using distilled water instead of DNA as a template.

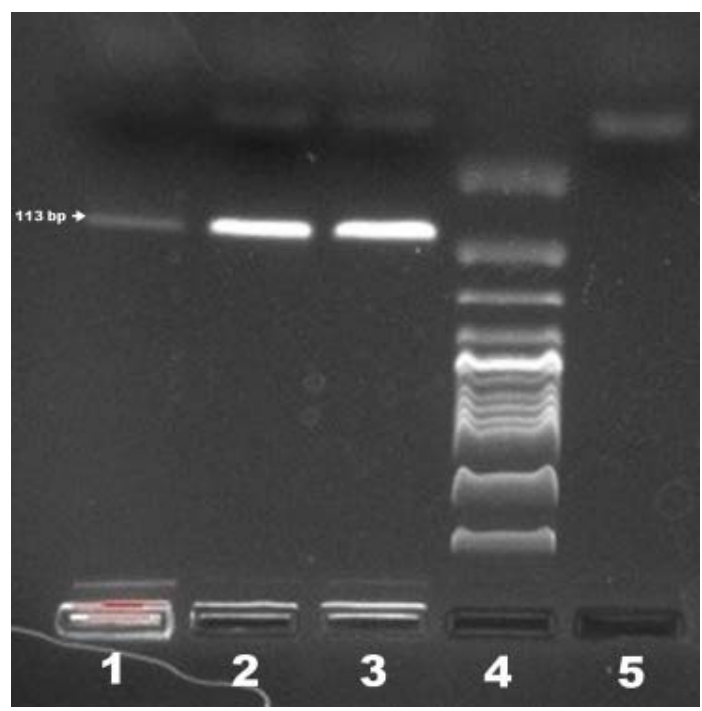

Figure 1. Conventional PCR for detection of Brucella spp. 1-2) Positive samples, 3) Positive control, 4) 100 bp ladder, 5) Negative control

Table 2 summarizes the distribution and relative intensity of Brucella spp. Antigens in the lung, liver, spleen, kidney, cardiac muscle, mesenteric lymph node, and thymus, as well as the expression of cleaved caspase-3 and LC3B in these tissue samples.

The immunohistochemical staining positivity of the antigen was strong in the lung, spleen, kidney, and thymus, it was moderate in the liver, mesenteric lymph nodes, and heart muscle, and it was slight in the brain and skeletal muscle (Table 2).

The immunostaining seemed to be concentrated mainly in the bronchiolar lumen exudate, consisting of lymphocytes, neutrophils, and macrophages. Immunostaining was also conspicuous in the bronchiolar epithelium, peribronchiolar mononuclear cellular infiltrates, and alveolar macrophages. Immunopositivity in the spleen was stronger in the red pulp, especially macrophages, compared to the white pulp. The concentration of Brucella spp. antigens was strongest in the glomeruli of the aborted fetal kidneys, followed by the tubular epithelium and intertubular tissue. The distribution of the antigen in the thymus was greatest in cortical lymphocytes, followed by the medulla, reticular cells, lymphocytes, and Hassall's corpuscles (Fig. 2). 
Table 2.

\begin{tabular}{|c|c|c|c|c|c|c|c|c|c|}
\hline & Lung & Liver & Spleen & Kidney & Brain & Heart & Muscle & L.nod. & Thymus \\
\hline 1 Brucella spp. antigens & 3 & 1 & 3 & 2 & 0 & 1 & 1 & NA & NA \\
\hline Cleaved Caspase 3 & 1 & 1 & 2 & 2 & 0 & 0 & 0 & NA & NA \\
\hline LC3B & 2 & 2 & 2 & 2 & 0 & 0 & 0 & NA & NA \\
\hline 2 Brucella spp. antigens & 2 & 1 & 3 & 2 & 0 & $0 *$ & 1 & NA & 3 \\
\hline Cleaved Caspase 3 & 1 & 0 & 1 & 1 & 0 & 0 & 0 & NA & 2 \\
\hline LC3B & 0 & 1 & 1 & 0 & 0 & 1 & 0 & NA & 2 \\
\hline 3 Brucella spp. antigens & 3 & 0 & 1 & 1 & 0 & 0 & 0 & 2 & 1 \\
\hline Cleaved Caspase 3 & 2 & 0 & 0 & 0 & 0 & 0 & 0 & 0 & 0 \\
\hline LC3B & 2 & 0 & 0 & 0 & 0 & 0 & 0 & 1 & 0 \\
\hline 4 Brucella spp. antigens & 3 & 1 & NA & 1 & 0 & 1 & 0 & 0 & 3 \\
\hline Cleaved Caspase 3 & 1 & 1 & NA & 0 & 0 & 0 & 0 & 0 & 2 \\
\hline LC3B & 1 & 1 & NA & 0 & 0 & 0 & 0 & 0 & 1 \\
\hline 5 Brucella spp. antigens & 1 & 1 & 3 & 2 & 1 & 1 & 0 & NA & 1 \\
\hline Cleaved Caspase 3 & 0 & 1 & 1 & 1 & 1 & 0 & 0 & NA & 1 \\
\hline LC3B & 0 & 0 & 0 & 1 & 1 & 0 & 0 & NA & 2 \\
\hline 6 Brucella spp. antigens & 3 & 1 & 2 & 2 & 0 & 1 & NA & NA & 3 \\
\hline Cleaved Caspase 3 & 3 & 1 & 2 & 0 & 0 & 0 & NA & NA & 2 \\
\hline LC3B & 1 & 1 & 2 & 1 & 0 & 0 & NA & NA & 1 \\
\hline 7 Brucella spp. antigens & 1 & $0^{*}$ & 2 & 1 & $0^{*}$ & 0 & 0 & 0 & NA \\
\hline Cleaved Caspase 3 & 1 & 1 & 0 & 1 & 0 & 0 & 0 & 0 & NA \\
\hline LC3B & 1 & 1 & 2 & 2 & 2 & 0 & 0 & 0 & NA \\
\hline 8 Brucella spp. antigens & 3 & 2 & 2 & 2 & 1 & 1 & $0 *$ & 0 & NA \\
\hline Cleaved Caspase 3 & 1 & 1 & 1 & 1 & 0 & 0 & 0 & 0 & NA \\
\hline LC3B & 2 & 2 & 2 & 1 & 1 & 0 & 1 & 0 & NA \\
\hline \multirow{3}{*}{$\begin{array}{l}9 \text { Brucella spp. antigens } \\
\text { Cleaved Caspase } 3 \\
\text { LC3B }\end{array}$} & 3 & 1 & 2 & 2 & 0 & 1 & NA & 2 & 1 \\
\hline & 2 & 1 & 1 & 1 & 0 & 0 & NA & 1 & 1 \\
\hline & 2 & 1 & 0 & 0 & 0 & 0 & NA & 1 & 1 \\
\hline \multirow{3}{*}{$\begin{array}{l}10 \text { Brucella spp. antigens } \\
\text { Cleaved Caspase } 3 \\
\text { LC3B }\end{array}$} & 2 & $0^{*}$ & 3 & 3 & 0 & 0 & 1 & 0 & 2 \\
\hline & 2 & 1 & 2 & 1 & 0 & 0 & 0 & 0 & 2 \\
\hline & 1 & 0 & 2 & 1 & 0 & 0 & 0 & 0 & 1 \\
\hline 11 Brucella spp. antigens & 1 & 1 & 2 & 2 & 0 & 1 & 0 & 2 & 1 \\
\hline \multirow{2}{*}{$\begin{array}{l}\text { Cleaved Caspase } 3 \\
\text { LC3B }\end{array}$} & 1 & 0 & 0 & 1 & 0 & 0 & 0 & 0 & 0 \\
\hline & 1 & 0 & 0 & 1 & 0 & 0 & 0 & 1 & 0 \\
\hline \multirow{3}{*}{$\begin{array}{l}12 \text { Brucella spp. antigens } \\
\text { Cleaved Caspase } 3 \\
\text { LC3B }\end{array}$} & 3 & 1 & 2 & 1 & 0 & 1 & 0 & 2 & 3 \\
\hline & 1 & 1 & 1 & 1 & 0 & 0 & 0 & 1 & 2 \\
\hline & 2 & 2 & 1 & 1 & 0 & 0 & 0 & 1 & 1 \\
\hline \multirow{3}{*}{$\begin{array}{l}13 \text { Brucella spp. antigens } \\
\text { Cleaved Caspase } 3 \\
\text { LC3B }\end{array}$} & 1 & 1 & 3 & 2 & 1 & 0 & 0 & 1 & 1 \\
\hline & 2 & 0 & 2 & 1 & 1 & 0 & 0 & 1 & 1 \\
\hline & 2 & 0 & 1 & 0 & 0 & 0 & 0 & 1 & 0 \\
\hline \multirow{3}{*}{$\begin{array}{l}14 \text { Brucella spp. antigens } \\
\text { Cleaved Caspase } 3 \\
\text { LC3B }\end{array}$} & 3 & 1 & 2 & 2 & 0 & 1 & 0 & $\mathrm{NA}$ & 3 \\
\hline & 3 & 1 & 1 & 1 & 0 & 0 & 0 & NA & 1 \\
\hline & 1 & 0 & 1 & 1 & 0 & 0 & 0 & $\mathrm{NA}$ & 1 \\
\hline \multirow{3}{*}{$\begin{array}{l}15 \text { Brucella spp. antigens } \\
\text { Cleaved Caspase } 3 \\
\text { LC3B }\end{array}$} & 2 & 1 & 1 & 1 & 0 & 0 & 0 & 1 & 1 \\
\hline & 1 & 0 & 0 & 1 & 0 & 0 & 0 & 1 & 0 \\
\hline & 0 & 0 & 1 & 1 & 0 & 0 & 0 & 0 & 0 \\
\hline \multirow{3}{*}{$\begin{array}{l}16 \text { Brucella spp. antigens } \\
\text { Cleaved Caspase } 3 \\
\text { LC3B }\end{array}$} & 3 & 2 & 1 & 3 & 0 & 0 & 0* & 1 & 2 \\
\hline & 2 & 1 & 1 & 1 & 0 & 0 & 0 & 0 & 1 \\
\hline & 1 & 2 & 1 & 1 & 0 & 0 & 1 & 0 & 1 \\
\hline \multirow{3}{*}{$\begin{array}{l}\text { Brucella spp. antigens } \\
\text { Cleaved Caspase } 3 \\
\text { LC3B }\end{array}$} & $37^{\mathrm{n}}$ & 15 & 32 & 29 & 3 & 9 & 2 & 11 & 25 \\
\hline & $24^{5}$ & 10 & 15 & $14^{s}$ & 2 & 0 & 0 & 4 & $15^{\Omega}$ \\
\hline & 17 & $13^{¥}$ & $16^{¥}$ & 13 & 2 & 0 & 0 & $5^{¥}$ & 11 \\
\hline
\end{tabular}

* Cases that is not detected Brucella spp. antigens were excluded from the study.

NA: not available, n: total, $₫$ tissues of apoptosis dominance, $¥$ tissues of autophagy dominance 

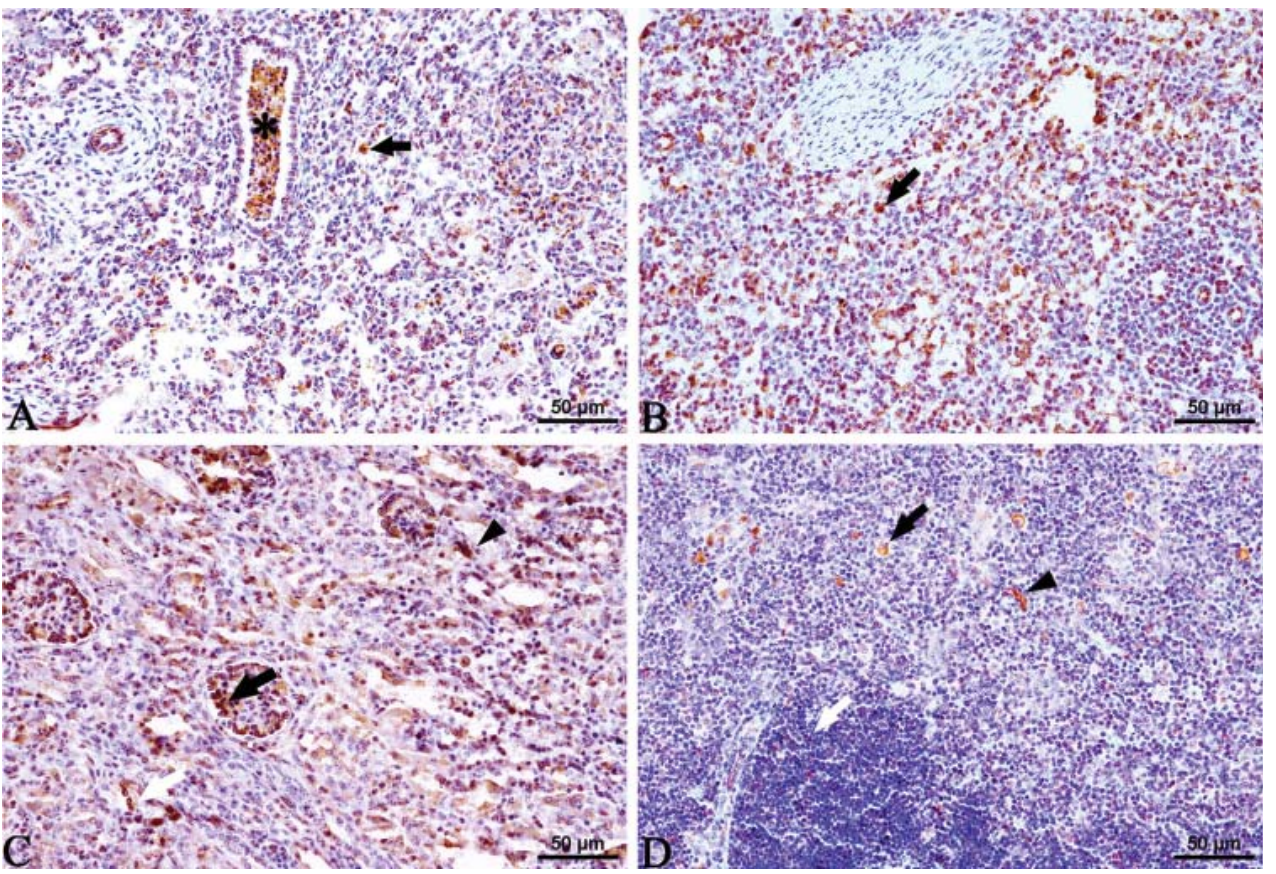

Figure 2. Brucella spp. antigens immunpositivity. Bronchiolar lumen $\left(^{*}\right)$ and macrophages (arrow) in lung (a). Macrophages (arrow) in spleen (b). Glomerul (arrow) and intertubular areas (arrowhead) in kidney (c). Lymphocytes (white arrow), reticular cells (arrow) and reticular fibers (arrowhead) in thymus (d).

The intrahepatic distribution, rated as moderate to light, favored Kupffer cells in the periportal areas and the bile duct epithelium. Positivity within mesenteric lymph nodes was found mainly in lymphoblasts in the medullary space. Distribution of the antigen was concentrated in the perivascular macrophage infiltrates and vascular endothelium in the myocardium. Slight immunopositivity was observed in the brain glial cells and mononuclear cell infiltrates in the skeletal muscle.

Immunopositivity for cleaved caspase-3 was present in all tissues, except the cardiac and skeletal muscles. It was prominent in the lung, thymus, spleen, kidney, and liver samples. The distribution of cleaved caspase- 3 in the lung resembled that of the Brucella spp. antigen, being most marked in the cellular exudate of the bronchiolar lumen, bronchiolar epithelium, and interstitial alveolar macrophages. In contrast, the staining in the thymus was concentrated in both cortical and medullary lymphocytes, as well as in medullary cells. In the kidney, only the tubular epithelium appeared immunopositive for caspase-3 (Fig. 3). The cellular distribution of cleaved caspase-3 in the other organs was as follows: macrophages, lymphocytes, and reticular cells in the spleen; periportalarea Kupffer cells and bile duct epithelium in the liver; lymphocytes and macrophages in the mesenteric lymph nodes; and glia cells in the brain (Fig. 4). 


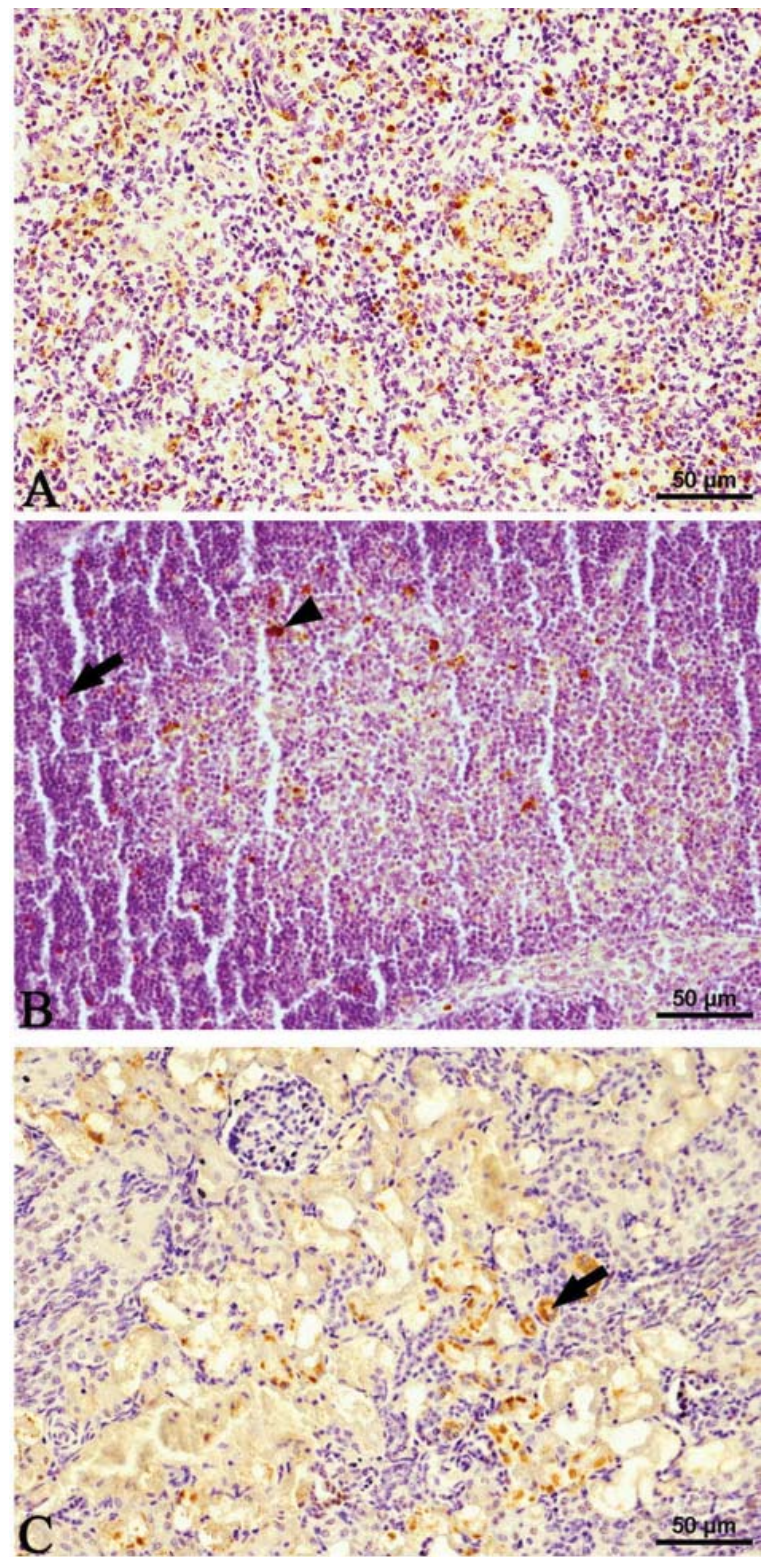

Figure 3. Cleaved caspase 3 immunpositivity. In lung (a). Lymphocytes (arrow) and macrophages (arrowhead) in the thymus (b). Tubules in the kidney (c).

All the tissues, except the cardiac and skeletal muscles, were positive for LC3B. In the lung, LC3B was found in the bronchiolar cellular exudate, bronchiolar epithelial cells, and interstitial and alveolar macrophages. In the kidney, immunopositivity was present in the glomeruli, with less immunostaining in the intertubular space macrophages and tubular epithelium cells. In the spleen, immunopositivity was found in macrophages, 

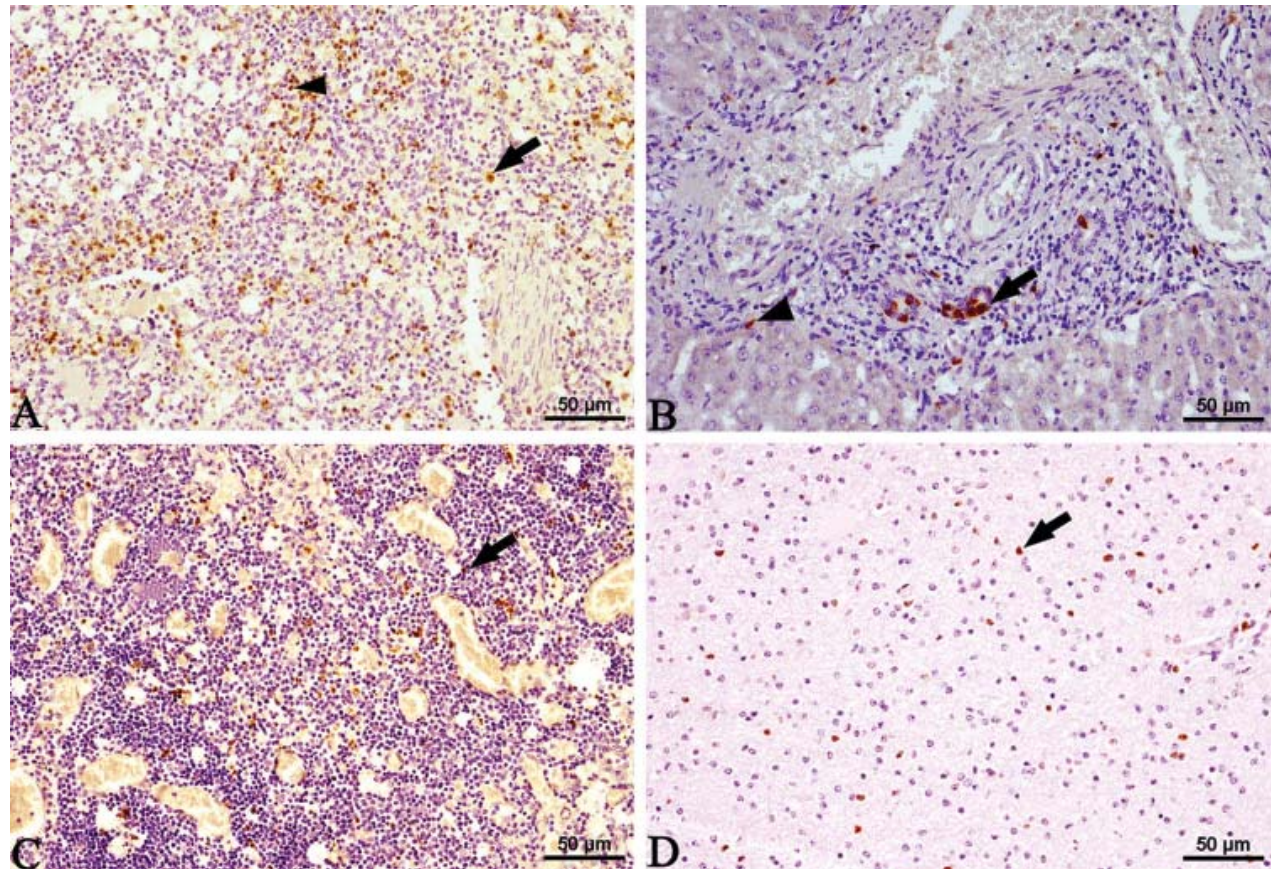

Figure 4. Cleaved caspase 3 immunpositivity. Macrophages (arrow) and lymphocytes (arrowhead) in spleen (a). Biliary duct epithelium (arrow) and periportal area (arrowhead) in the liver (b). Lymphocytes (arrowhead) in the lymphnode (c). Glial cells (arrow) in the brain (d).

lymphocytes, and reticular cells. In the liver, immunopositivity was detected in the periportal-area Kupffer cells. Finally, in the thymus, immunopositivity was found in lymphocytes, reticular cells, and macrophages (Fig. 5). The localization and intensity of LC3B in the brain tissue were parallel to those of cleaved caspase- 3 .

Immunopositivity for both indicators was higher in the liver, spleen, kidney, lung, and thymus than in the other organs. When the fixation of cleaved caspase- 3 was compared to that of $\mathrm{LC} 3 \mathrm{~B}$, the former was more intense in the liver, thymus, and kidney, and the latter was more apparent in the liver, spleen, and mesenteric lymph nodes (Table 2).

The expression of cleaved caspase- 3 and LC3B was rare in the tissues used as negative controls. There was a correlation between Brucella spp. and cleaved caspase-3 or LC3B positivity (Graph 1). 

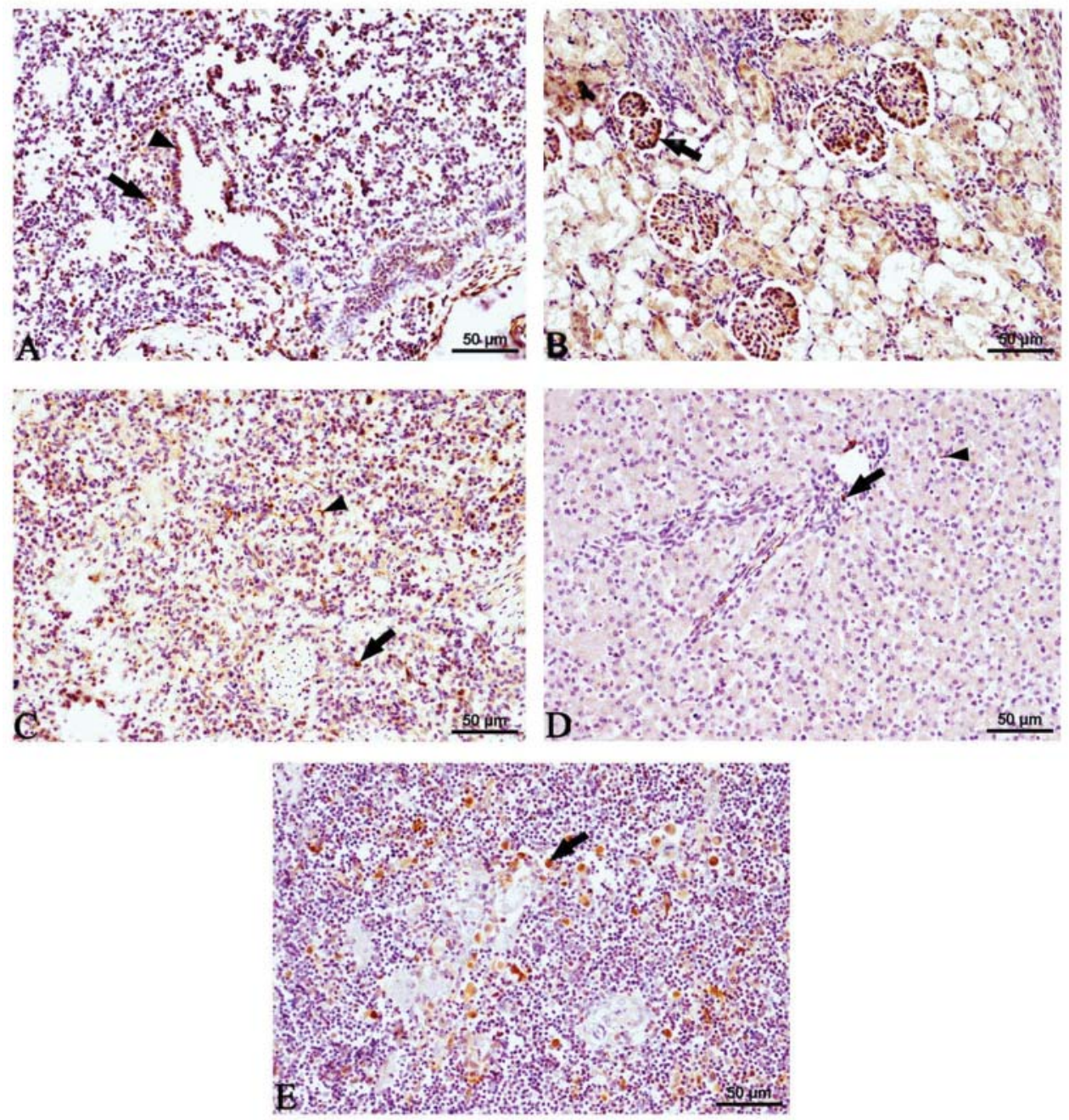

Figure 5. LC3B immunpositivity. Macrophages (arrow) and bronchial epitelium (arrowhead) in the lung (a). Glomerul (arrow) in the kidney (b). Reticular cells (arrowhead) and macrophages (arrow) in the spleen (c). Central vein (arrow) and Kupffer cells (arrowhead) in the liver. Epithelial cells (arrow) in the lympnodes (d). 


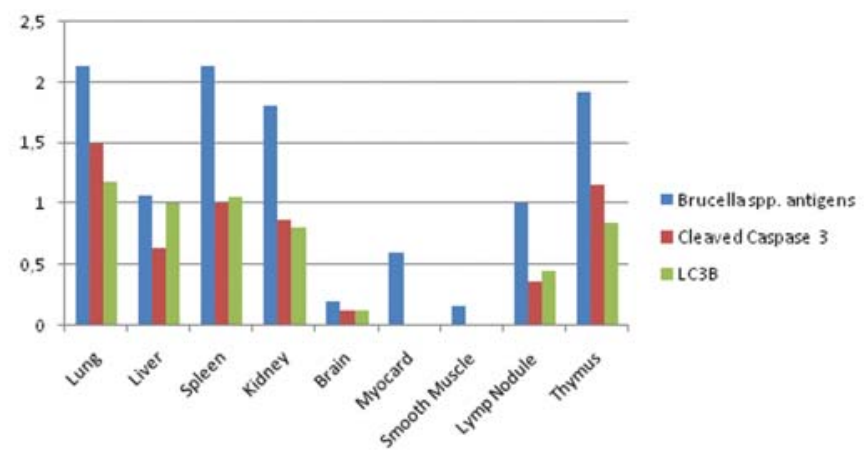

Graph 1. Proportion between Brucella spp. antigens, and Cleaved Caspase 3 and LC3B.

\section{DISCUSSION}

The distribution of Brucella spp. antigens and its relationship to apoptosis and autophagy were studied.

One of several methods used to diagnose Brucella spp. is immunohistochemistry. Immunohistochemistry is based on the detection of Brucella spp. antigens in tissue sections. Although this approach is not widely used, it is highly useful when studying the pathogenesis [5,20-22]. There are only a few reports on the distribution of Brucella spp. antigens in naturally infected bovine fetuses. Of those that have been published, the authors indicated that the immunohistochemical distribution was concentrated mostly in pulmonary macrophages, some neutrophils, and intra-alveolar cellular debris $[11,23]$, followed by spleen macrophages [24]. Brucella antigens were also found to be concentrated in periportal area infiltrates $[11,22]$ and biliary duct epithelial cells in the liver $[11,23]$, as well as in the perivascular cuff and macrophages in the brain $[5,25]$. A study of the distribution of Brucella spp. antigens from aborted cattle fetuses showed light expression in the kidney and no expression in the thymus [11]. In the present study, the concentration of Brucella spp. antigens in decreasing order were: lung, spleen, thymus, liver, mesenteric lymph nodes, heart muscle, brain, and skeletal muscle. This distribution is partially consistent with that found in earlier reports $[5,11,22,23,25]$. The difference in the distribution of the antigen may be due to variations in the bacterial strain and density.

Experimental studies using macrophage cell cultures and human macrophages showed that Brucella spp., an intracellular bacterium, triggered apoptotic cell death [26,27]. The genes regulating apoptosis are known as caspases [28]. Caspase-3, which is an executioner caspase, plays a crucial role in this mechanism. Caspase- 3 is activated by a dual mechanism, involving the participation of caspase- 8 in an intrinsic pathway and the 
participation of caspase-9 in an extrinsic pathway, leading to cellular apoptosis $[15,29]$. In the present study, immunopositivity was directly correlated with the distribution and intensity of the antigens in all the examined organs. Thus, this study indicates that apoptosis in spontaneous abortion related to Brucella spp. infection in cattle is similar to that reported for macrophages in cell cultures and human macrophages [26,27]. It has been suggested that cell death caused by intracellular pathogenic bacteria occurs not only through apoptosis but also via other pathways, such as necrosis [10]. There may be a complex interaction between apoptotic cell death and necrotic macrophage cell death. The term necrosis indicates a series of changes due to cell death that may be initiated by different mechanisms, including apoptosis [30,31]. Thus, it is possible that the Brucella-induced apoptotic and necrotic cell death of macrophages represent different stages of the same pathway, with apoptosis occurring in the early stages of infection and necrosis occurring in later stages. Non apoptotic cell death pathways induced in some macrophages may also lead to necrosis [10].

Autophagy caused by intracellular pathogenic bacteria has already been reported for various agents, such as Streptococcus pyogenes, Listeria monocytogenes, Salmonella enterica, Anaplasma phagocytophilum, and Shigella flexnerii [14,32]. Authophagy caused by Brucella spp. has also been studied, with autophagy mechanisms described in epithelial tissue cultures [33,34]. Autophagy-induced cell death was also clearly established in murine macrophage culture [35]. Most of the proteins known to participate in autophagy, named autophagy-related proteins, or Atg proteins, were discovered using studies on yeasts, with more than 30 Atg genes identified to date [36]. In mammals, the LC3B protein, corresponding to the Atg8 protein in yeast, was reported to play a particularly significant role in the autophagy mechanism [24,37]. The appearance of autophagic Brucella- containing vacuoles over time involves the acquisition of several autophagy proteins, such as Unc-51-like kinase 1 and Beclin 1. ATG5 and LC3B have been reported in autophagicBrucella-containing vacuoles [38,39]. In the present study, immune positivity for LC3B was directly correlated to the distribution and intensity of the antigen in all the examined organs. Given that cell culture studies have shown that Brucellaspp. can cause autophagy [16,18,40], the immune positivity for LC3B suggests that active autophagy is present in spontaneous bovine abortions due to Brucella spp. infection.

In conclusion, the present study demonstrated that the deaths of cells infected with Brucella spp. were attributable both to apoptosis and to autophagy, indicating that both cell death mechanisms may be activated by this infectious agent.

\section{Authors' contributions}

$\mathrm{MO}, \mathrm{SC}$ and $\mathrm{AOC}$ participated in the immunohistochemical examination. $\mathrm{AK}$ and $\mathrm{HO}$ participated in the PCR analysis. 


\section{Declaration of conflicting interests}

The author(s) declared no potential conflicts of interest with respect to the research, authorship, and/or publication of this article.

\section{REFERENCES}

1. Garrity GM: Bergey's Manual of SystematicBacteriology, 2nd ed. 2001, SpringerPress, New York.

2. Al Dahouk S, Tomaso H, Nockler K, Neubauer H, Frangoulidis D: Laboratory-based diagnosis of brucellosis--a review of the literature. Part II: serological tests for brucellosis. 2003, 49:57789.

3. Fensterbank R: Brucellosis in Cattle, SheepAndGoats. Oie Technical Series., 1987, 6:9-35.

4. Khamesipour F, Rahimi E, Shakerian A, Doosti A, Momtaz H: Molecular study of the prevalence of Brucella abortus and Brucella melitensis in the blood and lymph node samples of slaughtered camels by polymerase chain reaction (PCR) in Iran. Acta Vet.-Beograd 2014, 64:245-256.

5. Meador VP, Tabatabai LB, Hagemoser WA, Deyoe BL: Identification of Brucella abortus in formalin-fixed, paraffin-embedded tissues of cows, goats, and mice with an avidin-biotinperoxidase complex immunoenzymatic staining technique. Am J VetRes 1986, 47: 2147-50.

6. Bergsbaken T, Fink SL, Cookson BT: Pyroptosis: host cell death and inflammation. Nat Rev Microbiol 2009, 7: 99-109.

7. Bras M, Queenan B, Susin SA: Programmed cell death via mitochondria: different modes of dying. Biochemistry (Mosc) 2005, 70: 231-39.

8. Edinger AL, Thompson CB: Death by design: apoptosis, necrosis and autophagy. Curr Opin. Cell Biol 2004, 16: 663-69.

9. Hetz CA, Torres V, Quest AF: Beyond apoptosis: nonapoptotic cell death in physiology and disease. Biochem. Cell Biol 2005, 83: 579-88.

10. Gao LY, Kwa1k YA: The modulation of host cell apoptosis by intracellular bacterial pathogens. Trends Microbiol 2000, 8: 306.

11. Sozmen M, Erginsoy SD, Genc O, Beytut E, Ozcan K: Immunohistochemical and microbiological detection of Brucella abortus in aborted bovine fetuses. Acta Vet Brno 2004, 73; 465-72.

12. Earnshaw WC, Martins LM, Kaufmann SH: Mammalian caspases: structure, activation, substrates, and functions during apoptosis. Ann Rev Biochem 1999, 68; 383-424.

13. Joza N, Susin SA, Daugas E, Stanford WL, Cho SK, Li CYJ, Sasaki T, Elia AJ, Cheng HYM, Ravagnan L, Ferri KF, Zamzami N, Wakeham A, Hakem R, Yoshida H, Kong YY, Mak TW, Zúñiga-Pflücker JC, Kroemer G, Penninger JM: Essential role of the mitochondrial apoptosis inducing factor in programmed cell death. Nature 2001, 410; 549-54.

14. Levine B, Mizushima N, Virgin HW: Autophagy in immunity and inflammation. Nature 2011, 469; 323-35.

15. Mirkes PE: 2001 Warkany lecture: todie or not todie, the role of apoptosis in normal and abnormal mammalian development. Teratology 2002, 65; 228-39

16. Pizarro-Cerda J, Meresse S, Parton RG, Van Der Goot G, Sola-Landa A, Lopez-Goni I, Moreno E, Gorvel JP: Brucella abortus transits through the autophagic pathway and replicates in the endoplasmic reticulum of non professional phagocytes. Infect Immun 1998, 66; 5711-24. 
17. Klionsky DJ, Abeliovich H, Agostinis P, Agrawal DK, Aliev G, Askew DS, Baba M, et al.: Guidelines for the use and interpretation of assays for monitoring autophagy in higher eukaryotes, Autophagy 2008, 4; 151-75.

18. Pizarro-Cerda J, Moreno E, Sanguedolce V, Mege JL, Gorvel JP: Virulent Brucella abortus prevents lysosome fusion and is distributed within autophagosome-like compartments. Infect. Immun 1998, 66: 2387-92.

19. Leal-Klevezas DS, Martinez Vazquez IO, Lopez Merino A, Martinez-Soriano JP: Single-step PCR for detection of Brucella spp. from blood and milk of infected animals. J Clin Microb. 1995, 33: 3087-90.

20. López A, Hitos F, Perez A, Navarro-Fierro RR: Lung lesions in bovine fetuses aborted by Brucella abortus. Can J Comp Med 1984, 48; 275-77.

21. Santos RL, Peixoto MTD, Serakides R, Costa GM, Martins NE: : Detección de Brucella abortus (muestra B19) por el complejo inmunoenzimático avidina-biotina peroxidasa en el testículo y en el epidídimo de bovinos inoculados experimentalmente. Archivos de Reproduccion Animal 1998, 6; 34-41.

22. Xavier MN, Paixão TA, Poester FP, Lage AP, Santos RL: Pathological, 1mmunohistochemical and bacteriological study of tissues and milk of cows and fetuses experimentally infected with Brucella abortus. J Comp Path 2009, 140; 149-57.

23. Perez J, Quezada M, Lopez J, Casquet O, Sierra MA, Martin De Las Mulas J: Immunohistochemical detection of Brucella abortus antigens in tissues from aborted bovine fetuses using a commercially available polyclonal Antibody. J Vet Diagn Invest 1998, 10; 17-21.

24. Kabeya Y, Mizushima N, Ueno T, Yamamoto A, Kirisako T, Noda T, Kominami E, Ohsumi Y, Yoshimori T: LC3, a mammalian homologue of yeast Apg8p, is localized in autophagosome membranes after processing. EMBO J 2000, 19; 5720-28.

25. Hong CB, Donahue JM, Giles RCJR, Poonacha KB, Tuttle PA, Cheville NF: Brucella abortusassociated meningitis in aborted bovine fetuses. Vet Pathol 1991, 28; 492-96.

26. Chen F, He Y: Caspase-2 mediated apoptotic and necrotic murine macrophage cell death induced by rough Brucella abortus. Plos One 2009, 4; e6830.

27. Fernandez-Prada CM, Zelazowska EB, Nikolich M, Hadfield TL, Roop RM, Robertson GL, Hoover DL: Interactions between Brucella melitensis and human phagocytes: bacterial surface O Polysaccharide inhibits phagocytosis, bacterial killing, and subsequent host cell apoptosis. Infect Immun 2003, 71; 2110-19.

28. Metzstein MM, Stanfield GM, Horvitz HR: Genetics of programmed cell death in C. elegans: past, present and future. Trends Genet 1998, 14; 410-16.

29. Vermeulen K, Van Bockstaele DR, Berneman ZN: Apoptosis: mechanisms and relevance in cancer. Ann Hematol 2005, 84; 627-39.

30. Fink SL, Cookson BT: Apoptosis, pyroptosis, and necrosis: mechanistic description of dead and dying eukaryotic cells. Infect Immun 2005, 73; 1907-16.

31. Majno G, Joris I: Apoptosis, oncosis, and necrosis. An overview of cell death. Am J Pathol 1995, 146; 3-15.

32. Rikihisa Y: Mechanisms of obligatory intracellular infection with Anaplasma phagocytophilum. Clin Microbiol Rev 2011, 24; 469-89.

33. Niu H, Yamaguchi M, Rikihisa Y: Subversion of cellular autophagy by Anaplasma phagocytophilum. Cell Microbiol 2008, 10; 593-605.

34. Otto GP, Wu MY, Clarke M, Lu H, Anderson OR, Hilbi H, Shuman HA, Kessin RH: Macroautophagy is dispensable for intracellular replication of Legionella pneumophila in Dictyostelium discoideum. Mol Microbiol 2004, 51; 63-71. 
35. Guo F, Zhang H, Chuangfu C, Shengwei H, Yuanzhi W, Jun Q, Yan R, Zhang K, Yong W, Guoqing D: Autophagy Favors Brucella Melitensis Survival In Infected Macrophages. Cell. Mol Biol Lett 2012, 17; 249-57.

36. Xie Z, Klionsky DJ: Autophagosome formation: core machinery and adaptation. Nat Cell Biol 2007, 9; 1102-9.

37. Tanida I, Ueno T, Kominami E: Human light chain 3/MAP1LC3B is cleaved at its carboxylterminal Met121 to expose Gly120 for lipidation and targeting to autophagosomal membranes. J BiolChem 2004, 2794; 7704-10.

38. Figueiredo P, FichtTA, Rice-Ficht A, Rossetti CA, Adams LG: Pathogenesis and immunobiology of Brucellosis review of Brucella- host interactions. Am J Pathol, 2015, 185: 1505-1517.

39. Starr T, Child R, Wehrly TD, Hansen B, Hwang S, Lopez-Otin C, Virgin HW, Celli J: Selective subversion of autophagy complexes facilitates completion of the Brucella intracellular cycle. Cell Host Microbe 2012, 11:33-45.

40. Guo XL, Li D, Hu F, Song JR, Zhang SS, Deng WJ, Sun K, Zhao QD, Xie XQ, Song YJ, Wu MC, Wei LX: Targeting autophagy potentiates chemotherapy-induced apoptosis and proliferation inhibition in hepatocarcinoma cells, 28, 171-9. doi: 10.1016/j.canlet.2012.03.002.

\title{
ULOGA APOPTOZE I AUTOFAGIJE U ABORTUSU GOVEDA PROUZROKOVANOM SA BRUCELLA SPP.
}

\author{
OZKARACA Mustafa, CERIBASI Songul, CERIBASI Ali Osman, KILIC Ayse, \\ ONGOR Hasan
}

Ispitivanje je imalo za cilj evaluaciju intenziteta apoptoze $\mathrm{i}$ autofagije, u vezi sa prisustvom i distribucijom Brucella spp. antigena u tkivima pluća, jetre, bubrega, slezine, mozga, srca, skeletnih mišića, mezentarijalnih limfnih čvorova i timusa, poreklom od fetusa goveda koji su pobačeni tokom prirodne infekcije sa Brucella spp. Distribucija antigena Brucella spp. bila je ispitivana imunohistohemijskim metodama i to u tkivima poreklom od 16 pobačenih plodova kod krava kod kojih je dijagnostikovana bruceloza testom lančane reakcije polimeraze (PCR). Pored toga, radi detekcije apoptoze, obavljeno je imunohistohemijsko bojenje, upotrebom primarnih antitela (kaspaza 3). U cilju detekcije autofagije u navedenim tkivima, kod abortusa povezanih sa brucelozom, obavljeno je i imunohistohemijsko dokazivanje proteina (LC3B). Ispitivanja ćelijske smrti ukazala su da postoji jasna veza sa antigenima brucela u tkivima pluća, slezine, bubrega i timusa. Ova povezanost je bila srednjeg nivoa u slučaju tkiva jetre, mezenterijalnih limfnih čvorova i slaba u slučaju tkiva mozga i skeletnih mišića. $\mathrm{Na}$ osnovu imunohistohemijskih analiza imunopozitivnost u odnosu na kaspazu 3 i LC3B, bila je izražena u tkivima pluća, timusa, slezine, bubrega i jetre. Imunohistohemijska reakcija kaspaza 3 u tkivima pluća, timusa i bubrega, bila je izraženija u poređenju sa LC3B. U tkivima jetre, slezine i mezenterijalnih limfnih čvorova, imunopozitivnost na LC3B bila je veća u odnosu na kaspaza 3. U slučaju abortusa izazvanih sa Brucella spp, bakterijaki antigeni su lako mogli da se uoče u tkivnim uzorcima pluća, slezine, bubrega i timusa. Istovremeno je zapaženo da u ćelijskoj smrti značajnu ulogu imaju procesi apoptoze i autofagije. 